\title{
Front Matter: Volume 10166
}

, "Front Matter: Volume 10166," Proc. SPIE 10166, Industrial and Commercial Applications of Smart Structures Technologies 2017, 1016601 (2 May 2017); doi: $10.1117 / 12.2270664$

Event: SPIE Smart Structures and Materials + Nondestructive Evaluation and Health Monitoring, 2017, Portland, Oregon, United States 


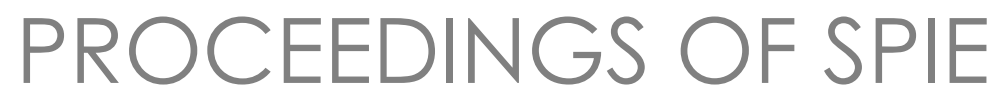

\title{
Industrial and Commercial Applications of Smart Structures Technologies 2017
}

\author{
Dan J. Clingman \\ Editor
}

\author{
26-27 March 2017 \\ Portland, Oregon, United States \\ Sponsored by \\ SPIE \\ Co-sponsored by \\ OZ Optics, Ltd. (United States) \\ Polytec, Inc. (United States) \\ Fiberguide Industries (United States) \\ Frontiers Media (Switzerland) \\ Cooperating Organization \\ Jet Propulsion Laboratory (United States) \\ Published by \\ SPIE
}


The papers in this volume were part of the technical conference cited on the cover and title page. Papers were selected and subject to review by the editors and conference program committee. Some conference presentations may not be available for publication. Additional papers and presentation recordings may be available online in the SPIE Digital Library at SPIEDigitallibrary.org.

The papers reflect the work and thoughts of the authors and are published herein as submitted. The publisher is not responsible for the validity of the information or for any outcomes resulting from reliance thereon.

Please use the following format to cite material from these proceedings:

Author(s), "Title of Paper," in Industrial and Commercial Applications of Smart Structures Technologies 2017, edited by Dan J. Clingman, Proceedings of SPIE Vol. 10166 (SPIE, Bellingham, WA, 2017) Seven-digit Article CID Number.

ISSN: 0277-786X

ISSN: 1996-756X (electronic)

ISBN: 9781510608177

ISBN: 9781510608184 (electronic)

Published by

SPIE

P.O. Box 10, Bellingham, Washington 98227-0010 USA

Telephone +1 3606763290 (Pacific Time) · Fax +1 3606471445

SPIE.org

Copyright @ 2017 , Society of Photo-Optical Instrumentation Engineers.

Copying of material in this book for internal or personal use, or for the internal or personal use of specific clients, beyond the fair use provisions granted by the U.S. Copyright Law is authorized by SPIE subject to payment of copying fees. The Transactional Reporting Service base fee for this volume is $\$ 18.00$ per article (or portion thereof), which should be paid directly to the Copyright Clearance Center (CCC), 222 Rosewood Drive, Danvers, MA 01923. Payment may also be made electronically through CCC Online at copyright.com. Other copying for republication, resale, advertising or promotion, or any form of systematic or multiple reproduction of any material in this book is prohibited except with permission in writing from the publisher. The CCC fee code is 0277-786X/17/\$18.00.

Printed in the United States of America.

Publication of record for individual papers is online in the SPIE Digital Library.

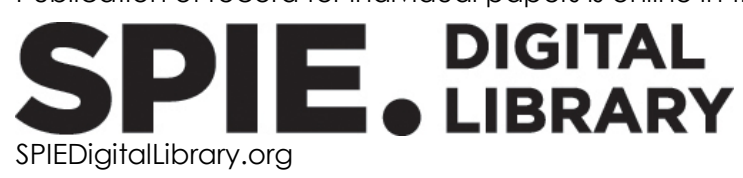

Paper Numbering: Proceedings of SPIE follow an e-First publication model. A unique citation identifier (CID) number is assigned to each article at the time of publication. Utilization of CIDs allows articles to be fully citable as soon as they are published online, and connects the same identifier to all online and print versions of the publication. SPIE uses a seven-digit CID article numbering system structured as follows:

- The first five digits correspond to the SPIE volume number.

- The last two digits indicate publication order within the volume using a Base 36 numbering system employing both numerals and letters. These two-number sets start with $00,01,02,03,04$ 05, 06, 07, 08, 09, OA, OB ... 0Z, followed by 10-1Z, 20-2Z, etc. The CID Number appears on each page of the manuscript. 


\title{
Contents
}

\author{
$\checkmark$ Authors \\ vii Conference Committee
}

\section{SESSION 1 ENERGY HARVESTING/SENSORS I}

1016602 A forty-year history of fiber optic smart structures (Invited Paper) [10166-1]

1016603 Examination of single-substance multiphase material distribution in a cylindrical container using acoustic wavenumber spectroscopy [10166-2]

1016604 A piezoelectric shock-loading response simulator for piezoelectric-based device developers [10166-3]

\section{SESSION 2 ENERGY HARVESTING/SENSORS II}

1016605 Piezoelectric-based hybrid reserve power sources for munitions [10166-4]

1016606 Modal analysis of a loaded tire with non-contact measurements and piezoelectric excitation [10166-5]

1016607 Wearable Spiral Passive Electromagnetic Sensor (SPES) glove for sign language recognition of alphabet letters and numbers: a preliminary study [10166-6]

1016608 A new class of monolithic seismometers and accelerometers for commercial and industrial applications: the UNISA folded pendulum [10166-7]

1016609 The development of two Broadband Vibration Energy Harvesters (BVEH) with adaptive conversion electronics [10166-8]

\section{SESSION 3 SMART MATERIALS AND APPLICATIONS I}

$10166 \mathrm{OB} \quad$ Bimorph-driven synthetic jet actuators optimized for various piezoelectric materials using a low-order model [10166-10]

10166 OC Self-tuning tuned mass damper (TMD) [10166-11]

10166 OD An electro-dynamic 3-dimensional vibration test bed for engineering testing [10166-12]

SESSION 4 SMART MATERIALS AND APPLICATIONS II

$10166 \mathrm{OE}$ Preliminary aeroelastic assessment of a large aeroplane equipped with a cambermorphing aileron [10166-13] 
$10166 \mathrm{OF}$ Touchscreen surface based on interaction of ultrasonic guided waves with a contact impedance [10166-14]

$101660 G$ Magnetorheological stabilizer bar for ground vehicles [10166-15]

\section{SESSION 5 SMART MATERIALS AND APPLICATIONS III}

$10166 \mathrm{OH}$ Challenges and the state of the technology for printed sensor arrays for structural monitoring [10166-16]

10166 Ol Reinforcing cementitious structures by $\mathrm{pH}$ activated in-situ shrinking microfiber [10166-17]

10166 0J A portable integrated system to control an active needle [10166-18]

10166 OK Auto-Gopher-II: an autonomous wireline rotary-hammer ultrasonic drill [10166-19]

$10166 \mathrm{OL}$ Experimental validation of a true-scale morphing flap for large civil aircraft applications [10166-20] 


\title{
Authors
}

Numbers in the index correspond to the last two digits of the seven-digit citation identifier (CID) article numbering system used in Proceedings of SPIE. The first five digits reflect the volume number. Base 36 numbering is employed for the last two digits and indicates the order of articles within the volume. Numbers start with 00, 01, 02, 03, 04, 05, 06, 07, 08, 09, OA, OB...0Z, followed by 10-1Z, 20-2Z, etc.

\author{
Ahmed, Riaz, OD \\ Amendola, Gianluca, OE \\ Amoroso, Francesco, OE, OL \\ Anderson, Nickolas, $\mathrm{OH}$ \\ Arena, Maurizio, OE, OL \\ Ashrafivon, Hashem, OJ \\ Badescu, Mircea, OK \\ Bai, Xian-Xu, OG \\ Banerjee, Sourav, OD \\ Bao, Xiaoqi, OK \\ Bar-Cohen, Yoseph, OK \\ Barone, F., 08 \\ Beaudet, Nicolas, OF \\ Bland, Scott, $\mathrm{OH}$ \\ Brzozowski, Daniel P., OB \\ Chesin, Jacob, OK \\ Clingman, Dan J., 09 \\ DeMott, Robert, $\mathrm{OH}$ \\ Dimino, Ignazio, OE \\ Feng, Z., 04 \\ Ferhat, Ipar, 06 \\ Flynn, Eric B., 03 \\ Giordano, G., 08 \\ Griffin, Steven F., OB, OC \\ Huston, Dryver R., Ol \\ Iervolino, Onorio, 07 \\ Jackson, Shannon, OK \\ Joshi, Shiv, $\mathrm{OH}$ \\ Jursich, Gregory, $\mathrm{OH}$ \\ Kim, Daniel, OK \\ Kim, Eric S., Ol \\ Konh, Bardia, 0J \\ Koskelo, Elise Anne C., 03 \\ Kwok, P., 05 \\ Lee, Hyeong Jae, OK \\ Lee, Patrick C., Ol \\ Lesieutre, George A., OB \\ Masson, Patrice, OF \\ Mellerowicz, Bolek, OK \\ Meo, Michele, 07 \\ Motalleb, Mahdi, 0J
}

\author{
Noviello, M. C., OL \\ O'Dowd, Niall M., 03 \\ Palumbo, Rita, OE \\ Paulsen, Gale L., OK \\ Pecora, Rosario, OE, OL \\ Quaegebeur, Nicolas, OF \\ Rastegar, J., 04, 05 \\ Rea, F., OL \\ Rees, John R., 03 \\ Saadatzi, Mohammad Nasser, OD \\ Saadatzi, Mohammadsadegh, OD \\ Sarret, Philippe, OF \\ Sassoon, Aaron M., OB \\ Scheel, Ingrid Udd, 02 \\ Shen, Sheng, OG \\ Sherrit, Stewart, OK \\ Tarazaga, Pablo A., 06 \\ Thiesen, Jack, 09 \\ Udd, Eric, 02 \\ $X U, S h i-X u, O G$ \\ $Y U$, Tianliang, $O B$ \\ Zacny, Kris, OK
}


Proc. of SPIE Vol. 10166 1016601-6

Downloaded From: https://www.spiedigitallibrary.org/conference-proceedings-of-spie on 26 Apr 2023 Terms of Use: https://www.spiedigitallibrary.org/terms-of-use 


\title{
Conference Committee
}

\author{
Symposium Chairs
}

Jayanth N. Kudva, NextGen Aeronautics, Inc. (United States)

Theodoros E. Matikas, University of loannina (Greece)

Symposium Co-chairs

Tribikram Kundu, The University of Arizona (United States)

Gregory W. Reich, Air Force Research Laboratory (United States)

Conference Chair

Dan J. Clingman, Boeing Research and Technology (United States)

Conference Program Committee

Steven R. Anton, Tennessee Technological University (United States)

Diann E. Brei, University of Michigan (United States)

Peter C. Chen, NASA Goddard Space Flight Center (United States)

Marcelo J. Dapino, The Ohio State University (United States)

Kevin M. Farinholt, Luna Innovations Inc. (United States)

Xiao-Yan Gong, Medical Implant Mechanics LLC (United States)

Steven F. Griffin, The Boeing Company (United States)

Nancy L. Johnson, General Motors Corporation (United States)

Jayanth N. Kudva, NextGen Aeronautics, Inc. (United States)

Amrita Kumar, Acellent Technologies, Inc. (United States)

Jung-Ryul Lee, KAIST (Korea, Republic of)

Donald J. Leo, The University of Georgia (United States)

Geoffrey P. McKnight, HRL Laboratories, LLC (United States)

Tobias Melz, Fraunhofer-Institut für Betriebsfestigkeit und

Systemzuverlässigkeit (Germany)

Christopher Niezrecki, University of Massachusetts Lowell (United States)

Gyuhae Park, Chonnam National University (Korea, Republic of)

W. Lance Richards, NASA Dryden Flight Research Center (United States)

Janet M. Sater, Institute for Defense Analyses (United States)

Edward V. White, The Boeing Company (United States)

Session Chairs

1 Energy Harvesting/Sensors I

Frederick Tad Calkins, The Boeing Company (United States)

2 Energy Harvesting/Sensors II

Dan J. Clingman, Boeing Research and Technology (United States) 
3 Smart Materials and Applications I

Bardia Konh, University of Hawai'i at Manoa (United States)

4 Smart Materials and Applications II

Bardia Konh, University of Hawai'i at Manoa (United States)

5 Smart Materials and Applications III

Christopher S. Lynch, University of California, Los Angeles (United States) 